\title{
ビス(2-ヒドロキシェチル)=テレフタラートの正蹜合蝶 $(\mathrm{Zn}(\mathbf{I I})$, $\operatorname{Co}(\mathrm{II}), M n(I I))$ の活性に与えるリン化合物の影需
}

\author{
唋谷 博善*1・小長谷 重次*1
}

(受付 1978 年 9 月 7 日・籰查終了 1978 年 11 月 4 日)

\begin{abstract}
要 旨 ビス(2-ヒドロキシェチル)=テレフタラートの直縮合触媒 $(\mathrm{Zn}(\mathrm{II}), \mathrm{Co}(\mathrm{II}), \mathrm{Mn}(\mathrm{II}))$ の

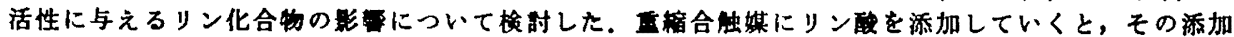

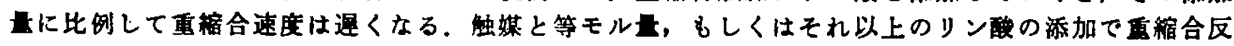

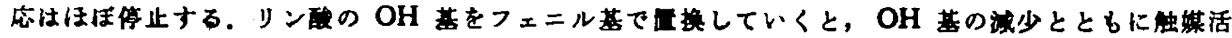
性への影零は少なくなり，トリフェニルホスフィンオキシドで触媒を注とんど失活させない，触媒 を失活させる順序を次に示古（ $(\mathrm{HO})_{8} \mathrm{PO}>\mathrm{C}_{6} \mathrm{H}_{8}(\mathrm{HO})_{2} \mathrm{PO}>\left(\mathrm{C}_{6} \mathrm{H}_{8}\right)_{2}(\mathrm{HO}) \mathrm{PO}>\left(\mathrm{C}_{6} \mathrm{H}_{8}\right)_{8} \mathrm{PO}$. 次に, リ

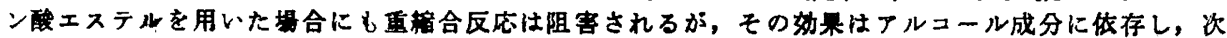

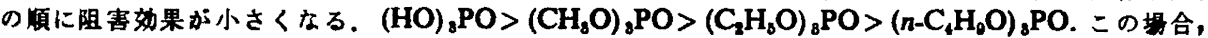

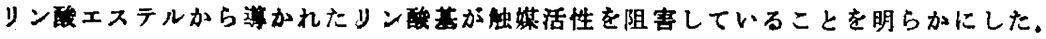

\section{1 緒 言}

金属化合物の存在下に，ビス(2-ヒドロキシェチル)= テレフタラート (BHET) あるいはそのオリダーを 重縮合させて高分子量ボリ(エチレンテレフタラート) (PET) を合成する祭に, 重綟合反応の進行とともに一部 副反応が起こり，PET の品筫が低下することが知られ ている1).これらの副反俯を㧕制するために, 通常重合触 媒ととむにリン化合物, 例えば, リン酸 ${ }^{2}$, 亜リン酸), ホスホン酸”もしくはその誘導(体2) 8) が併用される。 そ の結果, ボリマーの熱安定性が向上すると同時に, 色調 の優れた PET が得られることが確認されている。とこ ろが、リン化合物の種類により，その効果が異なると同 時飞重合速度に与える影数異なっている4),8),8)。

著者らはさきに, Co(II), $\mathrm{Zn}(\mathrm{II}), \mathrm{Mn}(\mathrm{II})$ 触媒の存在 下K BHET の重縮合反庆を行い，これらの触媒の作用 機構を明らかにした゚゙。本報では、リン化合物の効果を 解明するための第 1 段階として，これらの触媒にリン酸 もしくはその侨導体を添加して, 重合速度に与える影響 およびその原因について娭討した。

\section{2 実䛋}

\section{1 試料}

BHET はテレフタル酸とェチレンオキシドとの反応 で合成した ${ }^{10)}$. 触媒およびリン化合物は市肘特級品をそ のまま使用した。

*1 東洋紡縤 (株) 䋓合研究所 (6520-02 大津市本堅田 1300-1)

\subsection{BHET の五䀥合反忘}

既報早と同様に，BHET をオートクレーブ中で减圧下 に加熱し，生成するェチレングリコールを系外に除去し ながら重樎合反応を行った。

\section{3 分析}

\subsection{1 分子年の測定}

既報少と同様にフェノールと $1,1,2,2$-テトラクロロエ タンとの混合溶剤を用いて極限粘度 $[\eta]$ を測定した. 平 均重合度 $\left(P_{n}\right)$ は次式 (1) から求めた ${ }^{11)}$.

$$
[\eta]=7.55 \times 10^{-4}\left(192 P_{n}+62\right)^{0.688}
$$

\subsection{2 末端カルボキシル基の定目}

Pohl12) の方法に従って測定した. PET $0.1 \mathrm{~g}$ をべン ジルフルコールに加熱客解したあと，フェノールフタレ インを指示薬として $0.1 N$ 水覞化ナトリウムーベンジル フルコール溶夜で滴定して求めた。

2.3.3 ジエチレンクリコール (エーテル結合) の定旦 PET 中に含まれるエーテル 結合は, PET をエタ， ール分解した後, 遊奞してくるジェチレングリコール (DEG) をガスクロマトグラフを用いて定置した ${ }^{18)}$.

\subsection{4 反对スベクトルの珝定}

錠剤成形器を用いて作製した試料を(株)島津製作所製分 光光度計 RC-330 で測定した。

2.3.5 リン酸エステルとエチレンタリコールとの反 応生成物の测定

内容積 $200 \mathrm{ml}$ の三角フラスコに, リソ酸エステル $(0.2 \mathrm{~mol})$ とェチレングリコール $(0.72 \mathrm{~mol})$ を入れて $185^{\circ} \mathrm{C}$ の佰温槽中で加熱した。その際，反応で生成する 低沸点化合物を連続的に系外に取り出し，メスシリンダ 


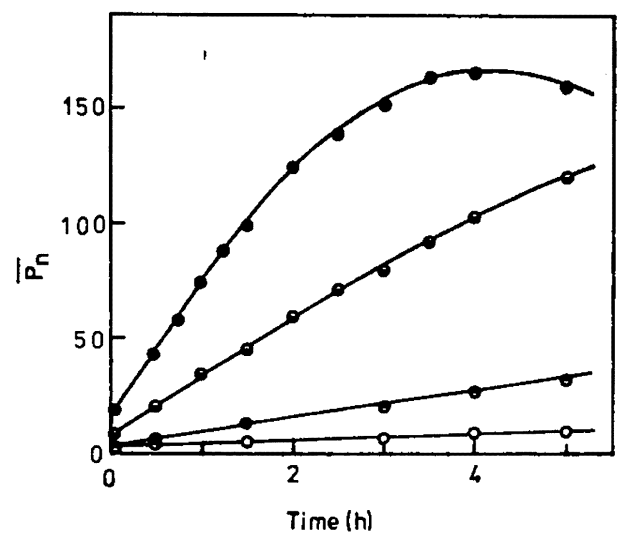

Fig. 1. Effect of the phosphoric acid concentration on the polycondensation rate of BHET in the presence of $\mathrm{Co}$ (II) catalyst: temp., $273^{\circ} \mathrm{C}$; pressure, $0.02 \mathrm{mmHg}$; BHET, 1.5 $\mathrm{mol}$; $\mathrm{Co}\left(\mathrm{OCOCH}_{8}\right)_{2} \cdot 4 \mathrm{H}_{2} \mathrm{O}, 0.30 \mathrm{mmol}$. $\mathrm{H}_{8} \mathrm{PO}_{4}$ (mmol): 0,$0 ; 0,0.15 ; 0,0.23 ; 0,0.30$.

一に受けて定量した，留出液の組成は，上記ガスク口 マトクラフで分析した。 カラム充てん用に PEG $20 \mathrm{M}$ (10\%)/chromosorb W (キシダ化学(株)製) $2 \mathrm{~m}$ を用 いた. カラム温度 $50^{\circ} \mathrm{C} \sim 200^{\circ} \mathrm{C}\left(6^{\circ} \mathrm{C} / \mathrm{min}\right)$, キャリャー ガスにーリウムを使用した。

\section{3 結果と考寮}

\section{$3.1 \mathrm{Co}(\mathrm{II}), \mathrm{Mn}(\mathrm{II}), \mathrm{Zn}$ (II) 虽媒に与えるリン酸 の此需}

リン酸の存在下に, 䣫酸コハルト(II) を触媒として, BHET の重縮合反応を行った。重合時間と，ボリマー の平均重合度 $\left(\boldsymbol{P}_{n}\right)$ との関係を Fig. 1 に示す. この図 から明らかなよらに，リン酸の添加豆の增加とともに， 重合速度は遅くなる。Co(II)，Mn(II)，Zn(II) 触媒の 旦を一定にして，リン酸の割合を变えた際の $P_{n}$ の变化 を Fig. 2 に示す.この場合, 触媒の種類を問わずリン 酸の添加量に比例して $\boldsymbol{P}_{n}$ が減少している. 触媒に対し て等モル量もしくはそれ以上のリン酸の添加で重縮合反 応はほとんど停止してしま5．既報の)のように，Co(II)， Mn(II)，Zn(II) 触媒による BHET の重粳合反応が BHET との錯体形成を経て進さことを考虚すると，上 記の実験孛実はリン酸の添加により別種の安定な錯体が 形成された可能性を示唆している. すなわら，リン酸を 添加しない系で酢酸コハルト(II) の存在下に BHET の 重樎合反応を行うと，まず触媒に結合している酢酸は BHET と配位子交換反応を行い，新しく BHET からの アルコキシドを含む錯体 [A] が生成する. 次いで錯体 [A] に更に BHET の生長末端である OH基が配位し,

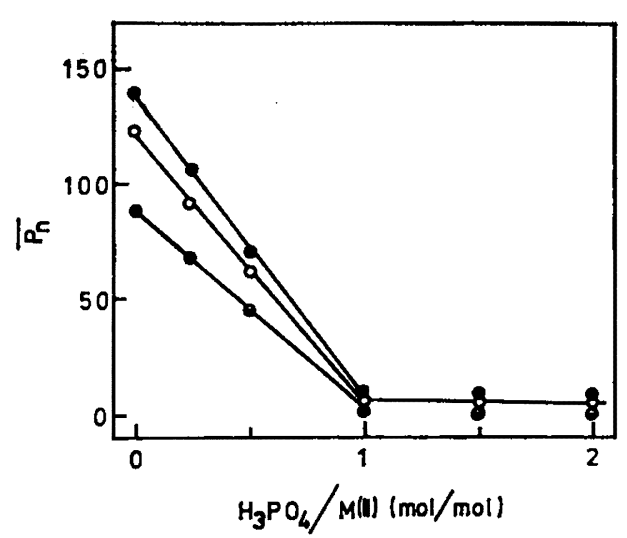

Fig. 2. Relationship between the degree of polymerization and the ratio of phosphoric acid to catalyst: temp., $273^{\circ} \mathrm{C}$; pressure, $0.02 \mathrm{mmHg}$; time, $2 \mathrm{hr}$; BHET, $1.5 \mathrm{~mol}$; catalyst, $0.3 \mathrm{mmol}$; $\mathrm{Zn}\left(\mathrm{OCOCH}_{8}\right)_{2} \cdot 2 \mathrm{H}_{2} \mathrm{O}$; O, $\mathrm{Co}\left(\mathrm{OCOCH}_{8}\right)_{2} \cdot 4 \mathrm{H}_{2} \mathrm{O} ; \ominus, \mathrm{Mn}\left(\mathrm{OCOCH}_{3}\right)_{2}$. $4 \mathrm{H}_{2} \mathrm{O}$.

錯体 [B] を形成する．この錯体内で BHET の末端 OH 基は中心金属に配位することにより活性が高められてい る. 重摍合反応は，この活性化された OH基が同じ鍺体 内で中心金属に配位しているカルボキシル基の炭䋈を攻 深することにより進んでいる(式 (2)).これらの錯体形 成については既に報告した゚゙。

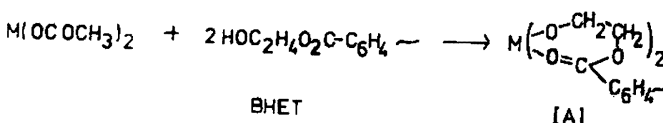

$$
\begin{aligned}
& |A|+2 \mathrm{HOC}_{2} \mathrm{H}_{4} \mathrm{O}_{2} \mathrm{C}_{6} \mathrm{C}_{4}-\rightarrow \mathrm{C}_{6} \mathrm{H}_{4}^{\prime} \\
& \text { [B] }
\end{aligned}
$$

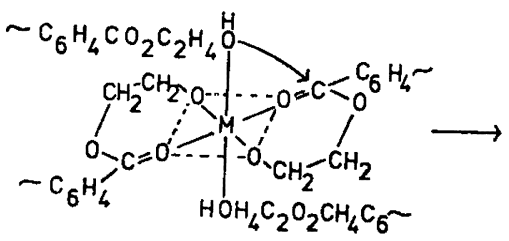

[B] 


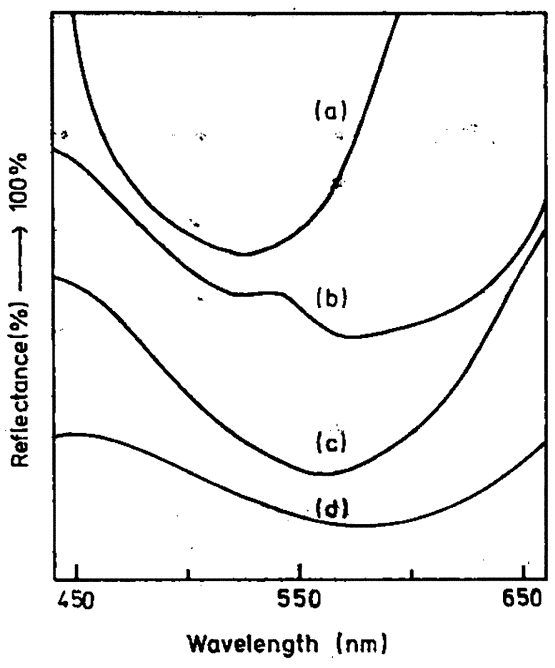

Fig. 3. Reflectance curves of cobaltous phosphate (a) and poly(ethylene terephthalate) prepared by the polycondensation of BHET in the presence of catalysts: catalyst, (b), Co $\left(\mathrm{OCOCH}_{8}\right)_{2} \cdot 4 \mathrm{H}_{2} \mathrm{O}+\mathrm{H}_{8} \mathrm{PO}_{6}$; (c) , $\mathrm{Co}\left(\mathrm{OCOCH}_{8}\right)_{2}$. $4 \mathrm{H}_{2} \mathrm{O}$; (d), $\mathrm{Co}\left(\mathrm{OCOCH}_{8}\right)_{2} \cdot 4 \mathrm{H}_{2} \mathrm{O}+\left(\mathrm{C}_{6} \mathrm{H}_{8}\right)_{3} \mathrm{PO}$.

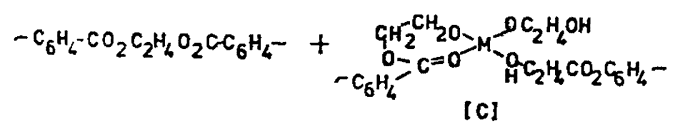

ただし，M=Co(II)，Mn(II), Zn(II)

一方，反応系に過剩のリン酸を添加した場合について みると，リン酸は水容液中で容易に䖵媒金属 $\mathrm{M}$ (II) と 反応して錯体 [D] となることが知られている10．<smiles>CC1(C)OP(=O)(O)OP1(C)(C)OP(=O)(O)O</smiles>

[D]

ただし，几 は水などの配位子

したがって，本実鋻条件下においてもりン酸のOH基 は，錯体 [B] の中心金属結合している BHET のフル コキシドと配位子交換反応を行い，新たにリン酸を含む 錯体 [D]が形成されるものと考えられる.このことは, リン酸添加系で重合し，そのまま錠剂に成形した PET の反射スベクトルからる支持される (Fig. 3). すなわち Co(II) のみを用いて重縮合させた PET の吸收は，565 $\mathrm{nm}$ 付近に吸収をむつブロードな単一ピークとして現れ
る (Fig. 3，c) のに反し，Co(II) にリン酸を添加すると $525 \mathrm{~nm}$ にも新しい呂収が現れる (Fig. 3，b)。リン酸 コバルトの吸収が $525 \mathrm{~nm}$ にある (Fig. 3，a) ことを 考虑すると，リン酸が関与した新しい鍺体 [D] が生成し ていると推定することができる．次いて䖝蝶に対するリ ン酸の剖合を少なくした场合の錯体の構造にういて考察 すると、リン酸の $\mathrm{OH}$ 基は触某金属に栖めて配位しゃ すいために，触某と等モル旦のリン酸を添加した手では リン酸の OH 基はすへてて触媒金属と結合し，高分子吾 の錯体，例光ば錩体 [E] むしくは [F]が生成していると 推定される18).10).

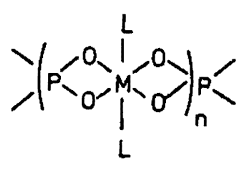

[E]

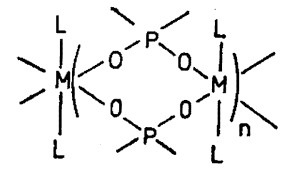

$[F]$
このことは副反応に基づくェーテル結合 (DEG) の 生成䩶から支持される.すなわちエーテル結合は錯体 [B]に拈いて中心金属に配位することにより活性化され た OH 基が同一錯体内でカルボキシラート基に隣接し たメチレン基を攻整することにより生成するが，むし くは酸触媒による BHET の脱水反応で生成することが 知られている ${ }^{17)}$. エーテル結合の生成がリン酸の添加に より促進されることは，Fig. 4 に示したように金属触 媒を添加せずにリン酸の存在下に BHET を反応させた 実匬結果からも明らかである。したがって，触媒に対し て等モル旦のリン酸を添加した場合，反応系に錯体 [E]

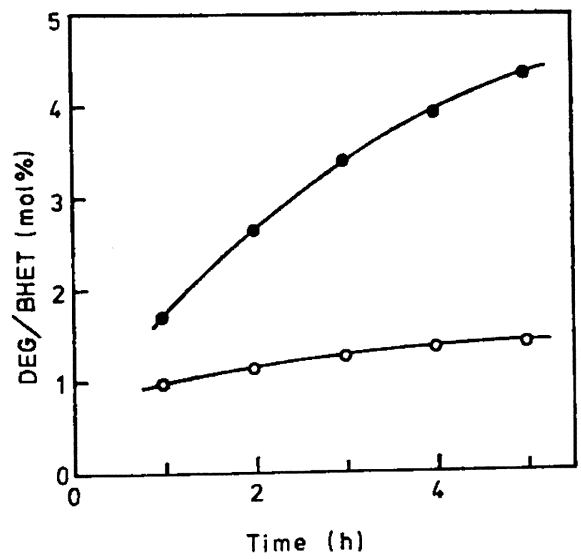

Fig. 4. Effect of phosphoric acid on the formation of ether linkage (DEG): temp., $273^{\circ} \mathrm{C}$; pressure, $0.02 \mathrm{mmHg}$; $O$, BHET $(1.5 \mathrm{~mol}) ; \bullet$, BHET (1.5 mol) $-\mathrm{H}_{8} \mathrm{PO}$ 、 $(0.3 \mathrm{mmol})$. 


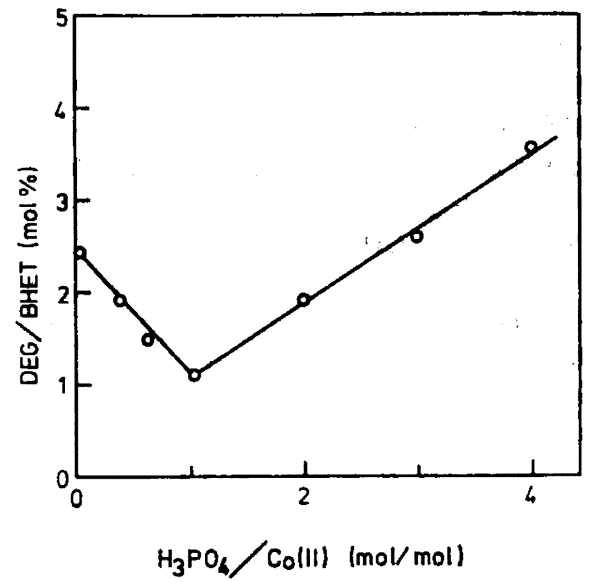

Fig. 5. Effect of the phosphoric acid concentration on the formation of ether linkage (DEG): temp., $273^{\circ} \mathrm{C}$; pressure, $0.02 \mathrm{mmHg}$; time, $2 \mathrm{~h}$; BHET, $1.5 \mathrm{~mol}$; $\mathrm{Co}\left(\mathrm{OCOCH}_{8}\right)_{2}$. $4 \mathrm{H}_{2} \mathrm{O}, 0.3 \mathrm{mmol}$.

もしくは [F] のみが存在すれば, 酸性のP-OH がなく なるためにェーテル結合の生成吾は取少になるはずであ $\eta$, Fig. 5 の実験結果とよく一致する.

\section{$3.2 \mathrm{Co}$ (II) 䖵媒に与えるリン酸の OH 基の影䉂} 前項で述へたように, Co(II), $\mathrm{Mn}$ (II)，Zn(II) 触媒 にリン酸を添加していくと，重合活性は低下する．この とき，リン醅の $\mathrm{OH}$ 基が触蝶と安定な結合をつくるこ とが触某を失活させるのに重要な役割を果していること を明らかにした。この点を更に確かめるために、リン酸 の $\mathrm{OH}$ 基をフェニル基もしくはアルキル基で直き替え たリン化合物を用いて触媒活性に与える影管を検討し た. Co(II) 触某の使用量を一定にして，リン化合物の 割合を変えた際の $P_{n}$ の変化を Fig. 6 に示す.

リン酸の OH 基をつェニル基で置換していくと, フ エニル基が增加するにつれて触媒活性を阻害する能力は 次の侕に低下する。

$$
\begin{aligned}
& (\mathrm{HO})_{8} \mathrm{PO}>\mathrm{C}_{6} \mathrm{H}_{5}(\mathrm{HO})_{2} \mathrm{PO}>\left(\mathrm{C}_{8} \mathrm{H}_{6}\right)_{2}(\mathrm{HO}) \mathrm{PO} \\
& >\left(\mathrm{C}_{6} \mathrm{H}_{6}\right)_{8} \mathrm{PO}
\end{aligned}
$$

このことは, リン酸の $\mathrm{OH}$ 基が触媒活性を低下させ るのに重要な役割を果していることを豆付けるものであ る.このとき，触媒は等モル量のリン酸でほほ完全に失 活するが, フェニルホスホン酸, むしくはジフェニルホ スフィン酸では触媒に対して2 倍むしくは3 倍モル用い ても触媒を完全に失活させることはできない：このこと はフェニル基がリン原子に結合することにより，P-OH 基の酸素の非共有電子対がリン原子の空の 3d 軌道を通 してフェニル基の $\pi$ 電子系と $\mathrm{P} \pi \mathrm{d} \pi$ 相互作用 ${ }^{18)}$ で共鳴 安定化するために，酸素原子の蚛媒金属への配位が弱め

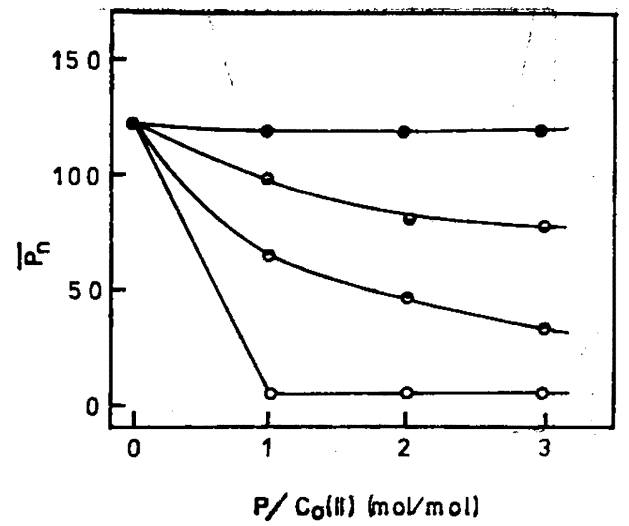

Fig. 6. Effect of phenylphosphorus compounds on the degree of polycondensation: temp., $273^{\circ} \mathrm{C}$; pressure, $0.02 \mathrm{mmHg}$; time, $2 \mathrm{~h}$; BHET, $1.5 \mathrm{~mol}$; $\mathrm{Co}\left(\mathrm{OCOCH}_{8}\right)_{2} \cdot 4 \mathrm{H}_{2} \mathrm{O}, 0.3 \mathrm{mmol}$. Phenylphosphorus compound: $\bullet,\left(\mathrm{C}_{6} \mathrm{H}_{5}\right)_{8} \mathrm{PO} ; \theta$. $\left(\mathrm{C}_{6} \mathrm{H}_{8}\right)_{2} \mathrm{P}(\mathrm{O})(\mathrm{OH}) ; \quad \Theta, \quad\left(\mathrm{C}_{6} \mathrm{H}_{8}\right) \mathrm{P}(\mathrm{O})(\mathrm{OH})_{2} ; \mathrm{O}$, $\mathrm{P}(\mathrm{O})(\mathrm{OH})_{8}$.

られたためと考えられる．特にリン酸の OH 基をすべ てフェニル基て置換したトリフェニルホスフィンオキシ ドでは触媒に対して大過剩用いても触媒活性はほとんど 低下しない，OH 基を持たないトリフェニルホスフィン オキシドが触媒金属に汪とんど配位しないことは次の実 結果からも支持される.すなわち，Co(II) 触媒にトリ フェニルホスフィンオキシドを添加しても，その PET の反射スペクトル (Fig. 3, d) は Co(II) 単独触蝶で重 合させた場合 (Fig. 3，c) と類似の反射スベクトルを示 し、リン酸を添加したときに認められる $525 \mathrm{~nm}$ 付近の 吸収は認められなかった。同様にして， OH 基を持たな いリン化合物, 例えばトリエチルホスフィンオキシド, トリフェニルホスフィン,トリブチルホスフィンなどを 添加した系で BHET の重縮合反応を行ってもその重合 速度はほとんど影管されなかった。

\subsection{Co(II) 䖵媒に与えるリン破エステルの影㛭}

今まで述へててきたりン化合物による触媒活性の低下 は, リン化合物の OH 基が触某金属に配位することに より引き起こされている. 添加郕として有効とされてい るリン酸エステルる触媒金属に配位することが知られて

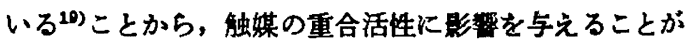
予想される. Co(II) 触媒に等モル量のリン酸アルキル エステルを添加した系で BHET の重箖合反応を行い, $P_{n}$ と重合時間との関係を調へた。結果を Fig. 7 に示 す.

リン酸エステルを用いた場合, 重合活性はフルコール 成分の影郚を受けフルコールの炭案数が隇少するほ 


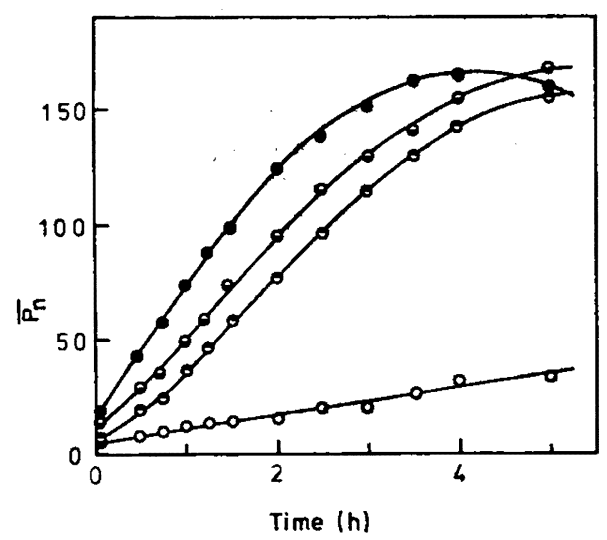

Fig. 7. Effect of trialkyl phosphate on the polycondensation rate of BHET: temp., $273^{\circ} \mathrm{C}$, pressure, $0.02 \mathrm{mmHg}$; BHET, $1.5 \mathrm{~mol}$; $\mathrm{Co}\left(\mathrm{OCOCH}_{3}\right)_{2} \cdot 4 \mathrm{H}_{2} \mathrm{O}, 0.3 \mathrm{mmol}$; trialkylphosphate, $0.3 \mathrm{mmol}$; $\ominus,\left(n-\mathrm{C}_{4} \mathrm{H}_{9} \mathrm{O}\right)_{3} \mathrm{PO} ; \Theta$, $\left(\mathrm{C}_{2} \mathrm{H}_{5} \mathrm{O}\right)_{3} \mathrm{PO} ; \quad \mathrm{O},\left(\mathrm{CH}_{3} \mathrm{O}\right)_{3} \mathrm{PO}$; O, without phosphorus compound.

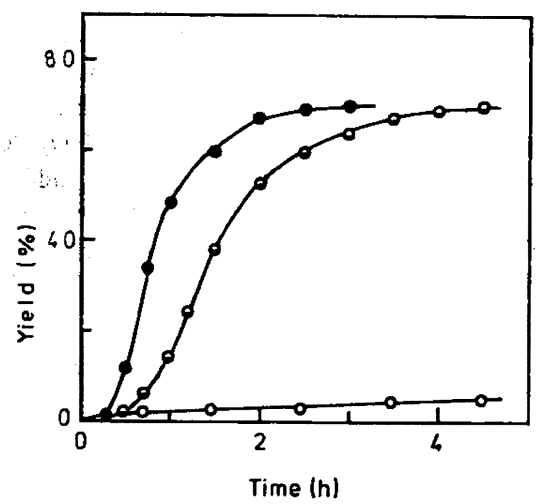

Fig. 8. Relationship between the reaction time and the yield of 2-alkoxyethanol in the reaction of trialkyl phosphate with ethylene glycol: temp., $185^{\circ} \mathrm{C}$; trialkyl phosphate, $0.2 \mathrm{~mol}$; ethylene glycol, $0.72 \mathrm{~mol} ; 0,\left(\mathrm{CH}_{8} \mathrm{O}\right)_{3} \mathrm{PO} ; \ominus$, $\left(\mathrm{C}_{2} \mathrm{H}_{8} \mathrm{O}\right)_{8} \mathrm{PO} ; \mathrm{O},\left(n-\mathrm{C}_{4} \mathrm{H}_{9} \mathrm{O}\right)_{3} \mathrm{PO}$.

ど,すなわち $\left(n-\mathrm{C}_{4} \mathrm{H}_{8} \mathrm{O}\right)_{8} \mathrm{PO}<\left(\mathrm{C}_{2} \mathrm{H}_{6} \mathrm{O}\right)_{8} \mathrm{PO}<\left(\mathrm{CH}_{8} \mathrm{O}\right)_{8}$ PO の順に重合活性怟下する。 Co(II) 触蝶に対して 等モル量のリン酸トリブチルを添加しても重縮合反応恃 はとんど阻害されないのに反し、リン酸トリォチルでは 著しく抑制される。一方，反応の留出液についてみる と、リン酸トリメチルを添加した釆では留出液中に2-メ トキシェタノールが検出されることから，リン酸エステ ルは重縮合過程で BHET と反応した可能性が考劣られ
る. そこでこの点を確かめるために BHET の代わりに エチレングリコールを用いて，無触媒下にリン破エステ ルと反応させ, その留出液を調べた。留出液の主成物は 2ーフルコキシェタノールであり，その他にリン酸エステ ルからのフルコールが少青含まれている. Fig. 8 に2-フ ルコキシェタノールの留出青と反応時间との関係を示 ち.

留出夜中に2-アルコキシェタノールが含まれているこ とは, エチレンクリコールの OH 基がリン酸エステル の酸素に隣接した炭菜原子を求核的に攻蜀したことを示 しておりこの場合，2-フルコキシェタノールと同時に リン酸基が生成するはずである(式 (3)).

$>\stackrel{\mathrm{O}}{\mathrm{P}-\mathrm{OR}}+\mathrm{HOC}_{2} \mathrm{H}_{4} \mathrm{OH} \longrightarrow>_{\mathrm{P}-\mathrm{OH}}^{\mathrm{O}}+\mathrm{ROC}_{2} \mathrm{H}_{4} \mathrm{OH}$

たたし， Rはアルキル基を示す.

この点を考园すると，Fig. 8 に示した 2-アルュキシ エタノールの生成速度は, 同時にリン酸基の生成速度を 示しており, その速度は $\left(n-\mathrm{C}_{6} \mathrm{H}_{8} \mathrm{O}\right)_{8} \mathrm{PO}<\left(\mathrm{C}_{2} \mathrm{H}_{6} \mathrm{O}\right)_{8} \mathrm{PO}$ $<\left(\mathrm{CH}_{8} \mathrm{O}\right)_{8} \mathrm{PO}$ の順に早くなっているといえる.この 祭, 触媒金属 (Co(II), Mn(II), Zn(II)) が存在する と, リン酸の生成と同時に錯体 [E] むしくは [F] が生 成するむのと考えられる20). したがって，リン酸エステ ルを用いた場合には，リン酸エステル自身が触媒を失活 させたのではなく，反応の中間に生成したリン酸基が触 媒を失活させた可能性を示している.このように，リン 酸エステルからリン酸基の生成速度が重合速度を支配し ているものであるならば, リン酸エステルと BHET と の反応を完結した後, 重縮合反応を行えば, リン酸エス テルの種類に関係なく，重縮合反応は停止するはずであ る.この点を確かめるために，まず Co(II) 触媒と等モ ル年のリン酸×ステルの存在下に BHET を $260^{\circ} \mathrm{C} て ゙$ 60分間常圧下に反応を行ったあと, 減圧下に重縮合を行 った.この場合はリン酸エステルの種類に同俰なく，取 初から等モル量のリン酸を添加した場合と同棣, 重縮合 反応は進まなかった。したがってリン酸エステルを用い た場合には，リン酸エステルからリン酸基が生成する速 度が律速となり，触媒は反応系に存在するリン酸基によ って失活したものと結論できる。

路辞本研究の報告に当たり，発表を碎可された東

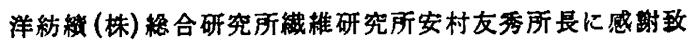
しますとともに, 論文作成に御指導, 御助吾を睗わった 大阪大学野桜俊一教授, 薄池幹治助教授に深䝰いたしま †.

\section{文获}

1) L.H. Buxbaum, Angew. Chem. Internat. 
Edit., 7, 182 (1968).

2) Du Pont, U.S. Patent 3,028, 366 (1962).

3) Imperial Chem. Ind., 日特公昭 32-6897.

4) 帝人，日特公昭 46-6314。

5) 合数レイヨン，日特公昭 44-29272.

6) 旭化成工羍，日特公昭 50-4710。

7) 箠紡, 日公昭 50-6350.

8) H. Zimmerman, Faserforsh. U. Textiltechn., 15, 481 (1962).

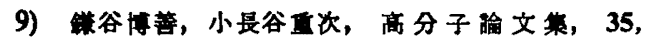
787 (1978).

10) 谷管, 日本化学会被, 1977, 1505 .

11) H. Yokoyama, T. Sano, T. Chijiwa, and R. Kajiya, J. Jpn. Petrol. Inst., 21, 58 (1978).

12) H.A. Pohl, Anal. Chem., 26, 1614 (1954).

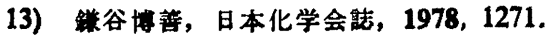

14) W.G. Palmer, "Experimental Inorganic Chemistry", Cambridge University Press, Cambridge, 1954, p. 459.

15) J. Danielsen and S.E. Rasmussen, Acta Chem. Scand., 17, 1971 (1963).

16) Z. Kolařik and R. Grimm, J. Inorg. Nucl. Chem., 38, 1721 (1976).

17) H.R. Penton, Jr. and H. Bouman, Polym. Prepr. 17, 521 (1976).

18）啝本直樹, 化学の颃域, 29, 254 (1975).

19) P.J. Quilley and G. A. Webb, Coord. Chem. Rev., 12, 407 (1974).

20) R.C. Paul, R.S. Battu, V.P. Kapila, J.C. Bhatia, and K.C. Malhotra, Indian J. Chem., 10, 447 (1972).

Effect of Phosphorus Compounds on the Activity of Catalyst (Zn(II), Co(II), Mn(II)) in the Polycondensation of Bis (2-hydroxyethyl) Terephthalate

Hiroyoshi Kamatani*1 and Shigeji Konagaya*1

${ }^{* 1}$ Katata Research Center, Toyobo Co., Ltd. (1300-1, Honkatata, Otsu, 520-02 Japan)

As the first step to clarify the role of phosphorus compounds in the catalytic polycondensation of bis (2-hydroxyethyl) terephthalate, effect of phosphorus compounds on the activity of catalyst ( $\mathrm{Zn}$ (II), $\mathrm{Co}(\mathrm{II}), \mathrm{Mn}$ (II)) was studied. When phosphoric acid was used, the polycondensation rate decreased linearly with increasing its molar ratio to the catalyst and the reaction practically did not proceed on addition of phosphoric acid of molar equivalent to the catalyst or more. The unfavorable effect of phenylphosphorus compounds decreased in the following order; $(\mathrm{HO}){ }_{8} \mathrm{PO}>\mathrm{C}_{6} \mathrm{H}_{8}(\mathrm{HO})_{2} \mathrm{PO}>$ $\left(\mathrm{C}_{6} \mathrm{H}_{6}\right)_{2}(\mathrm{HO}) \mathrm{PO}>\left(\mathrm{C}_{6} \mathrm{H}_{6}\right)_{8} \mathrm{PO}$, the effect of triphenylphosphine oxide being negligible. By the addition of a trialkyl phosphate the activity of catalyst also decreased depending upon its alcohol component in the following order; $(\mathrm{HO})_{3} \mathrm{PO}>\left(\mathrm{CH}_{3} \mathrm{O}\right)_{8} \mathrm{PO}>\left(\mathrm{C}_{2} \mathrm{H}_{8} \mathrm{O}\right)_{8} \mathrm{PO}>\left(n-\mathrm{C}_{4} \mathrm{H}_{8} \mathrm{O}\right)_{8} \mathrm{PO}$. It was made clear that this inhibitory effect of trialkyl phosphates is due to the complexation of the catalyst with phosphoric acid which was formed in situ in the early stage of the polycondensation.

KEY WORDS Bis (2-hydroxyethyl) Terephthalate / Poly (ethylene terephthalate) / Polycondensation / Phosphorus Compounds / Polycondensation Catalyst /

(Received September 7, 1978: Accepted November 4, 1978)

[Kobunshi Ronbunshu, 36(5), 293-298 (1979)] 